\title{
Australian Journal of \\ Effects of plant density on growth, yield and seed quality of quinoa genotypes under rain-fed conditions on red basalt soil regions
}

\author{
Nguyen Van Minh ${ }^{1 \mathrm{a}}$, Dinh Thai Hoang ${ }^{2 a}$, Nguyen Van Loc $^{2}$, and Nguyen Viet Long ${ }^{2 *}$ \\ ${ }^{1}$ Faculty of Agriculture and Forestry, Tay Nguyen University, Dak Lak, 63100 \\ ${ }^{2}$ Faculty of Agronomy, Vietnam National University of Agriculture, Hanoi, 131000 \\ ${ }^{\text {a } C o-f i r s t ~ a u t h o r, ~ * C o r r e s p o n d i n g ~ a u t h o r: ~ n v l o n g @ v n u a . e d u . v n ~}$
}

Abstract

Because of rainfall shortage, quinoa has the potential to supersede traditional crops that contribute to agricultural production less effectively. The current study determined the quinoa genotypes and plant density suitable for production under rain-fed conditions in red basalt soil regions. The experiments were conducted in the rainy and dry seasons of 2018/2019 using split-plot designs with three replications. In these, the main factor consisted of four quinoa genotypes and the subfactor four plant densities (13.3, 10.0, 8.0 and 6.6 plants $\mathrm{m}^{-2}$ ) with a row interval of $50 \mathrm{~cm}$ and a plant interval of $15,20,25$ and $30 \mathrm{~cm}$, respectively. The current study's results showed that plant density significantly affected polynomial trends on panicle length, panicle number/plant, seed number/panicle, 1000-seed weight, seed yield, protein content, and ash content. The plant density of 8.0 plants $\mathrm{m}^{-2}$ seems to be the optimal density for quinoa under the studied conditions. Results here also indicate significant differences among quinoa genotypes for agronomical and seed quality performance. Better performances of quinoa occurred in the dry season compared to the rainy season. Atlas and Cahuil were the best adaptive quinoa genotypes in the red basalt soil regions.

Keywords: basalt soil, plant density, quinoa, seed quality.

\section{Introduction}

Quinoa (Chenopodium quinoa Willd.) originated in South America, and it has been growing as a staple food crop for the continent's inhabitant for 10,000 years. Recently, quinoa has been considered as world crop (FAO, 2013). Parameters for a world crop include: i) high-quality values with sufficient nutrient composition; ii) high tolerance to environmental stress such as temperature, drought or saline stress; and finally iii) high economic benefit, especially under difficulty cultivated conditions.

In Vietnam, researchers and farmers first grew quinoa from 1986 to 2000 , with a variety of $\mathrm{HV}_{1}$ in the northern part with a yield that ranged from 14,0 to 20,6 quintal ha ${ }^{-1}$ (Trinh, 2001). Bertero et al. (2004) also reported that quinoa adapted well to Vietnam's cultivated conditions with higher yield compared to several original regions. Beginning in 2014, researchers and farmers have again been developing quinoa in different agro-ecological zones via cooperation between Vietnam and Argentina governments (Dinh et al., 2015; Nguyen et al., 2016a).

With relatively flat and large topography, the Central highland region is considered favorable for developing quinoa production. Basalt soil is a major soil in Central highland, accounting for $24.1 \%$ (around 1.45 million ha) of the total natural soil in this region. More than $92 \%$ of this type of soil is red basalt soil. This is an acidity and mold soil with thick cultivated layers and relatively high organic matter, nitrogen, and phosphorus content but low potassium; such conditions are suitable to cultivate many perennial and annual crops such as coffee, tea or maize (Trinh et al., 2019). The major agricultural production in this region has been perennial crops, which contributed substantially to Vietnam's agricultural export values. Soon, the current agricultural production will be less effective because over $70 \%$ of the production area is now experiencing rain-fed conditions (World Bank, 2016). Given such information, we proposed that quinoa production in this region could contribute to food security under climate change. To develop quinoa production in any region and soil condition, along with selecting the most suitable varieties, determining the optimal cultural density is necessary. This study accordingly evaluates the effects of plant density on growth, yield and seed quality of introduced quinoa genotypes as a means to suggest the optimal growing density for quinoa under rain-fed conditions in red bazal soil regions.

\section{Results and discussion}

\section{Effect of plant density on agronomical and seed yield traits}

The statistical analysis showed significant differences among plant densities for agronomical traits including panicle length, panicle number, seed number, 1000-seed weight, individual and actual yield, but plant height was insignificant (Table 1). There were upward trends in changes of seed number, 1000-seed weight and individual yield according to reducing plant density. Plant height, panicle length, panicle number, and actual yield changed in polynomial trends by increasing, then decreasing, 
following a drop in plant density to D3 (8.0 plants $\mathrm{m}^{-2}$ ) (Table 2). Increasing density, the competition in sunlight leads to higher plant height among the denser population. Nevertheless, nutrient and water competition may lead to reductions of plant height and other growth parameters in the denser population owing to shortages in nutrient supplement. An optimal density will support the growth balance to achieve the highest grain yield. In Brazil, Spehar and Rocha (2009) found that increasing density from 100,000 to 600,000 plants $h^{-1}$ had a negative effect on plant height, though it did not affect grain and biomass yield, nor did it affect 1000 grain weight. In Egypt with sparser density, Eisa et al. (2018) found there was an increase of plant density from 56,000 to 167,000 plants ha ${ }^{1}$ and decreased 1000-seed weight, but also increased seed yield by $34.7 \%$. In Argentina, Erazzú et al. (2016) reported that plant height, stem diameter, and grain yield were higher in sowing density of 70,000 plants ha ${ }^{-1}$ compared to 460,000 plants ha $^{-1}$. Delatorre et al. (1995) found little difference in plant height and yield among three densities of $27,600,83,000$ and 322,000 plants $h^{-1}$ (Delatorre, 2003). Similarly, Isobe et al. (2015) reported that the differences in seed yield of NL-6 quinoa variety were insignificant among plant densities in both narrow and wider row distances. Sief et al. (2015) reported that grain yield of quinoa changed in the same trend when increased plant densities at narrow interspacing row treatments $(20 \mathrm{~cm})$, but in opposite trend at wider spacing. In the northern part of Vietnam, Nguyen et al. (2016b) reported that plant density was not associated with the morphological performance of quinoa under saline stress conditions. Under non-stress conditions, Nguyen et al. (2018) also found that plant density had no effect on the number of panicle, panicle length, or 1000-seed weight, while yield increased from 7.8 to $36.9 \%$ when plant density increased from 130,000 to 160,000 and 200,000 plants ha' 1 . Trinh et al. (2001) also reported that plant density did not affect plant height or panicle length of HV1 var quinoa, whereas individual yield increased when plant density decreased from 166,666 to 47,620 plants $h^{-1}$. At the same time, actual yields were optimal when plant density ranged from 83,333 to 111,111 plants $\mathrm{ha}^{-1}$. In the current study, we found that plant density had no effect on the fat, fiber and starch contents of quinoa genotypes, whereas protein and ash content increased when plant density decreased (Table 3). The protein content of quinoa at D3 (80 plants $\mathrm{m}^{-2}$ ) The protein content of quinoa at D3 (8.0 plants $\mathrm{m}^{-2}$ ) was significantly higher than those at other densities, excepting D4 (6.6 plants $\mathrm{m}^{-2}$ ). At D3 and D4, the ash contents of quinoa was significantly higher than D1 (13.3 plants $\mathrm{m}^{-2}$ ) (Table 4). Such results agree with Eisa et al. (2018), who found that protein and ash concentrations in seeds were higher at lower planting density. They also reported that there was no significant difference between two planting densities regarding the concentrations of the detected crude fiber and total fat in quinoa seeds. Similarly, Sief et al. (2015) found increased protein content in quinoa seeds when plant density was lesser. However, Nguyen et al (2018) found no difference among plant densities in the contents of protein, fat, fiber, ash, starch and sugar.

\section{Variation of quinoa genotypes on agronomical and seed yield traits}

The current study found the differences among quinoa genotypes for all target traits (Table 1, 3). Among investigated genotypes, Atlas was the best for all agronomical traits, with its significantly higher values for panicle length and actual yield than others. Meanwhile, plant height, panicle length and actual yield of Cahuil were significantly higher than those of Moradas and 2-want. Cahuil and Atlas also showed the highest values for fiber content. Atlas also had the highest protein content (18.49\%) followed by Cahuil (15.68\%). Meanwhile, Cahuil had the highest fat content by a significant factor. Cahuil and Moradas had the highest ash content. Moradas and 2-want showed the highest values for starch contents, significantly higher than that Atlas did. Previous studies found differences among investigated quinoa cultivars in agronomical traits such as plant height, panicle length, number of panicles, 1000-seed weight and grain yield (Maliro and Njala, 2019; Präger et al., 2018; Tan and Temel, 2018; Naneli et al., 2017; Santis et al., 2016, Nguyen et al., 2016a, b). Präger et al. (2018) and Santis et al. (2016) identified differences in seed quality traits, including protein, fiber, and fat content.

\section{Genotype and plant density interaction for agronomical and seed yield traits}

In this study, the interactions between plant density and genotypes were insignificant except for 1000-seed weight in both seasons (Table 1). The difference in response of genotypes to different environments often occurs because of the strong effect of genetic and environment interaction, but especially with the participation of a larger number of genotype or more different locations. Maliro and Njala (2019), Naneli et al. (2018), and Tan and Temel (2018) found significant interactions of genotype and location in their experiments, but in the case of fewer genotypes or less different environments, the effect of the interaction of genetic and environment was less significant. In peanuts, there was significant interaction between genotype and year, but the interaction of genotype and water regime within a year was insignificant (Dinh et al., 2013, 2014). Similarly, Dinh et al. (2018) found no interaction between sugarcane genotype and water regime. In quinoa, there were similar results in the interaction between year and genotype (Präger et al., 2018; Santis et al., 2016), and between genotype and nitrogen level (Dinh et al., 2015).

Interestingly, the performance of genotype at different plant densities were similar between two growing seasons and seemed to be better in the dry season (Table 2). Meanwhile, yield of other crops, such as maize in dry season, is remarkably lower compared to that in the favorite season (summer-autumn/rainy season) (Nguyen et al., 2020). One could grow quinoa in different areas with greatly various precipitation, from Ecuadorian Andean with rainfall amount of 600 to $880 \mathrm{~mm}$ to Northern Chile with 50 to $100 \mathrm{~mm}$ of rainfall (FAO, 2011). In this study, higher rainfall supported better vegetative growth, with higher plant height, number of branches, and panicles per plant. However, heavy rainfall and more humid air conditions might affect reproductive growth with lower seed number per panicle as well as seed weight, leading to lower individual and actual yield compared to the dry season. The results of our study are similar to Dinh et al.'s (2015) results in the northern area where there were 1.6 to 2.1 times higher yields in the winter-spring season (dry and cold season) than in springsummer season (wet and warm season). Such results suggest that quinoa could adapt well in the Central highland, and especially in the dry season. 
1. ANOVA analysis of plant height, panicle length, panicle number, seed number/panicle, 1000-seed weight, individual yield, and actual yield

\begin{tabular}{|c|c|c|c|c|c|c|c|}
\hline Source & Plant height & Panicle length & ${ }_{1}^{\text {Panicle number plant }}$ & ${ }_{1}^{\text {Seed number panicle }}$ & 1000-seed weight & Individual yield & Actual yield \\
\hline \multicolumn{8}{|c|}{ Rainy season 2018} \\
\hline Density (D) & ns & $* * *$ & $*$ & $* *$ & $* * *$ & $* * *$ & $* *$ \\
\hline Genotype (G) & $* * *$ & $* * *$ & $* *$ & $* * *$ & * & $* * *$ & $* * *$ \\
\hline$D^{*} G$ & ns & Ns & ns & ns & $* *$ & ns & ns \\
\hline \multicolumn{8}{|c|}{ Dry season $2018 / 2019$} \\
\hline Density (D) & ns & $*$ & $*$ & $* *$ & $* * *$ & $* * *$ & $* *$ \\
\hline Genotype (G) & $* * *$ & $* * *$ & $* *$ & $* * *$ & * & $* * *$ & $* * *$ \\
\hline$D^{*} G$ & ns & Ns & ns & ns & * & ns & ns \\
\hline
\end{tabular}

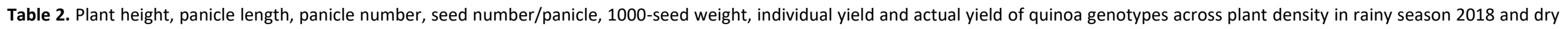
season 2018/2019

\begin{tabular}{|c|c|c|c|c|c|c|c|c|c|c|c|c|c|c|}
\hline \multirow[t]{2}{*}{ Treatment } & \multicolumn{2}{|c|}{$\begin{array}{l}\text { Plant height } \\
\text { (cm) }\end{array}$} & \multicolumn{2}{|c|}{$\begin{array}{l}\text { Panicle length } \\
(\mathrm{cm})\end{array}$} & \multicolumn{2}{|c|}{ Panicle number plant ${ }^{-1}$} & \multicolumn{2}{|c|}{ Seed number panicle ${ }^{-1}$} & \multicolumn{2}{|c|}{$\begin{array}{l}\text { 1000-seed weight } \\
\text { (g) }\end{array}$} & \multicolumn{2}{|c|}{$\begin{array}{l}\text { Individual yield } \\
\text { (g plant }^{-1} \text { ) }\end{array}$} & \multicolumn{2}{|c|}{$\begin{array}{l}\text { Actual yield } \\
\text { (quintal ha }{ }^{-1} \text { ) }\end{array}$} \\
\hline & Rainy & Dry & Rainy & Dry & Rainy & Dry & Rainy & Dry & Rainy & Dry & Rainy & Dry & Rainy & Dry \\
\hline \multicolumn{15}{|l|}{ Density } \\
\hline D1 & 102.8 & 97.2 & $18.6^{c}$ & $19.7^{c}$ & $25.4^{b}$ & $24.2^{b}$ & $214.9^{c}$ & $240.2^{c}$ & $2.27^{c}$ & $2.42^{\mathrm{C}}$ & $13.6^{c}$ & $13.8^{\mathrm{C}}$ & $14.5^{\mathrm{c}}$ & $16.3^{c}$ \\
\hline D2 & 102.5 & 96.9 & $19.1^{\mathrm{bc}}$ & $20.2^{\mathrm{bc}}$ & $26.9^{\mathrm{ab}}$ & $25.8^{\mathrm{ab}}$ & $237.1^{\mathrm{b}}$ & $262.4^{\mathrm{b}}$ & $3.06^{\mathrm{b}}$ & $3.21^{\mathrm{b}}$ & $21.2^{\mathrm{b}}$ & $21.4^{\mathrm{b}}$ & $17.3^{\mathrm{ab}}$ & $19.1^{\mathrm{ab}}$ \\
\hline D3 & 107.3 & 101.7 & $21.0^{a}$ & $22.1^{\mathrm{a}}$ & $28.9^{\mathrm{a}}$ & $27.7^{\mathrm{a}}$ & $257.0^{\mathrm{ab}}$ & $282.4^{\mathrm{ab}}$ & $3.62^{\mathrm{a}}$ & $3.74^{\mathrm{b}}$ & $28.3^{\mathrm{a}}$ & $28.4^{\mathrm{a}}$ & $18.9^{\mathrm{a}}$ & $20.6^{\mathrm{a}}$ \\
\hline D4 & 104.9 & 99.3 & $19.9^{b}$ & $21.0^{\mathrm{b}}$ & $27.3^{\mathrm{ab}}$ & $26.2^{\mathrm{ab}}$ & $259.3^{\mathrm{a}}$ & $284.6^{\mathrm{a}}$ & $3.87^{\mathrm{a}}$ & $3.97^{\mathrm{a}}$ & $29.4^{a}$ & $29.6^{a}$ & $16.2^{\mathrm{bc}}$ & $17.6^{\mathrm{bc}}$ \\
\hline \multicolumn{15}{|l|}{ Genotypes } \\
\hline Cahuil & $108.6^{\mathrm{a}}$ & $103.0^{\mathrm{a}}$ & $22.2^{b}$ & $23.3^{b}$ & $27.9^{\mathrm{ab}}$ & $26.7^{\mathrm{ab}}$ & $243.5^{\mathrm{a}}$ & $269.8^{\mathrm{a}}$ & $3.21^{\mathrm{ab}}$ & $3.33^{\mathrm{ab}}$ & $16.4^{c}$ & $24.0^{\mathrm{ab}}$ & $17.5^{b}$ & $19.2^{b}$ \\
\hline Atlas & $113.1^{\mathrm{a}}$ & $107.5^{\mathrm{a}}$ & $23.7^{\mathrm{a}}$ & $24.8^{\mathrm{a}}$ & $28.6^{\mathrm{a}}$ & $27.4^{\mathrm{a}}$ & $255.7^{\mathrm{a}}$ & $281.1^{\mathrm{a}}$ & $3.31^{\mathrm{a}}$ & $3.43^{\mathrm{a}}$ & $21.3^{\mathrm{a}}$ & $26.1^{\mathrm{a}}$ & $20.5^{\mathrm{a}}$ & $22.5^{a}$ \\
\hline Moradas & $95.7^{b}$ & $90.1^{b}$ & $16.0^{c}$ & $17.1^{c}$ & $25.8^{b}$ & $24.6^{b}$ & $223.8^{b}$ & $249.1^{b}$ & $3.27^{\mathrm{ab}}$ & $3.42^{\mathrm{ab}}$ & $19.6^{\mathrm{ab}}$ & $21.3^{\mathrm{b}}$ & $14.0^{c}$ & $15.4^{c}$ \\
\hline 2-want & $100.1^{b}$ & $94.5^{b}$ & $16.6^{c}$ & $17.7^{c}$ & $26.3^{\mathrm{b}}$ & $25.2^{b}$ & $245.3^{\mathrm{a}}$ & $270.7^{\mathrm{a}}$ & $3.03^{b}$ & $3.15^{\mathrm{b}}$ & $18.3^{\mathrm{bc}}$ & $21.7^{\mathrm{b}}$ & $14.9^{c}$ & $16.4^{c}$ \\
\hline
\end{tabular}



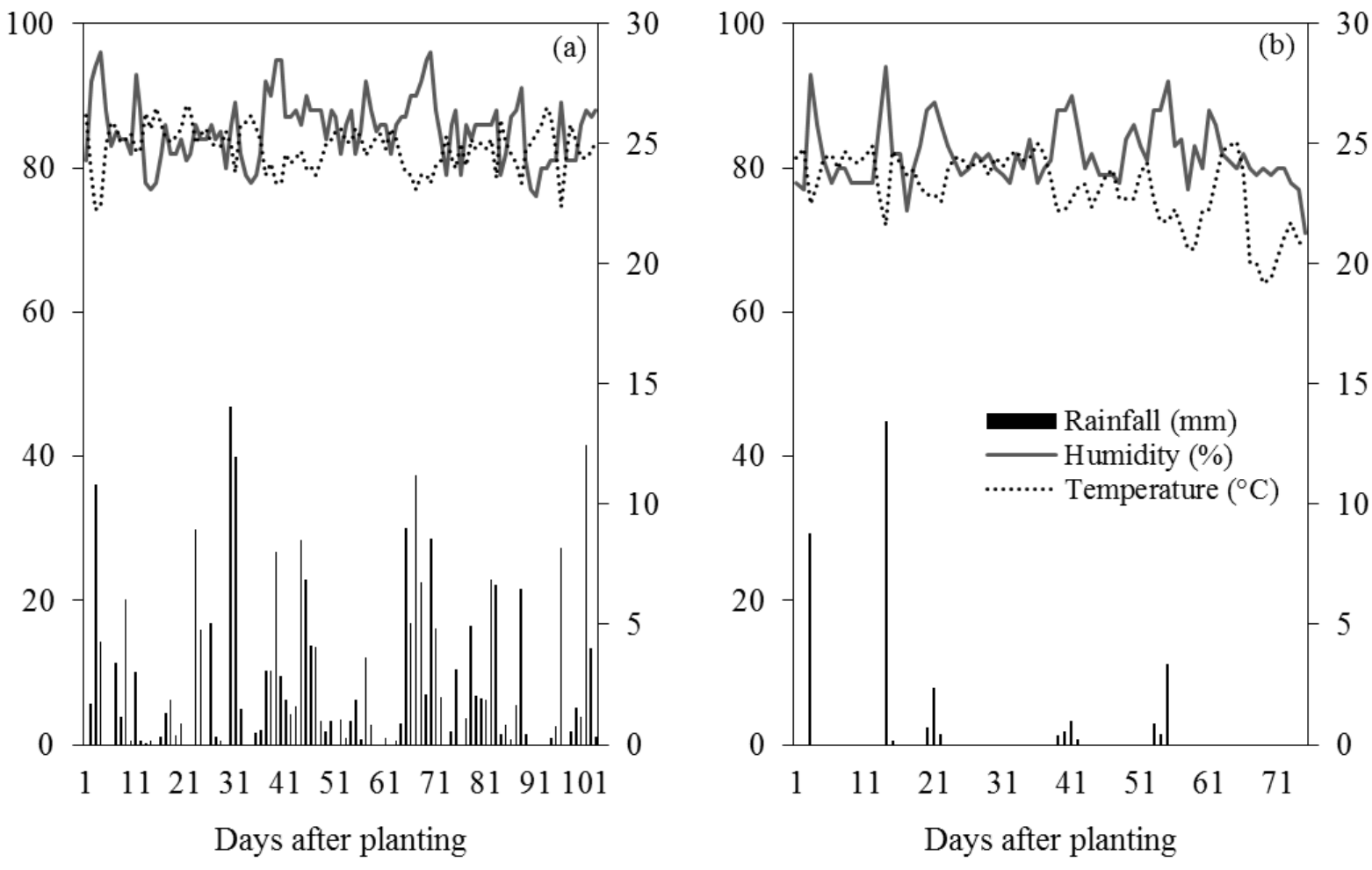

Fig 1. Meteorological conditions in the experimental field during rainy season 2018 (a) and dry season 2018/2019 (b).

Table 3. ANOVA analysis of fat, fiber, protein, ash and starch content.

\begin{tabular}{llllll}
\hline Source & Fat & Fiber & Protein & Ash & Starch \\
\hline Density (D) & ns & ns & $* *$ & $*$ & $n s$ \\
Genotype (G) & $* * *$ & $* * *$ & $* * *$ & $* * *$ & $* *$ \\
D*G & ns & ns & ns & ns & ns \\
\hline
\end{tabular}

$\mathrm{ns},{ }^{*}, * *$ and ${ }^{* * *}$ mean non-significant, significant at $\mathrm{P}<0.05, \mathrm{P}<0.01$ and $\mathrm{P}<0.001$, respectively.

Table 4. Fat, fiber, protein, ash and starch content of quinoa genotypes across plant density in dry season 2018/2019.

\begin{tabular}{llllll}
\hline Treatment & Fat (\%) & Fiber (\%) & Protein (\%) & Ash (\%) & Starch (\%) \\
\hline Density & & & & & \\
\hline D1 & 3.67 & 6.94 & $15.88^{\mathrm{c}}$ & $1.64^{\mathrm{b}}$ & 69.23 \\
D2 & 3.63 & 6.90 & $15.93^{\mathrm{bc}}$ & $1.67^{\mathrm{ab}}$ & 68.67 \\
D3 & 3.69 & 6.98 & $16.34^{\mathrm{a}}$ & $1.70^{\mathrm{a}}$ & 69.01 \\
D4 & 3.72 & 6.91 & $16.17^{\mathrm{ab}}$ & $1.70^{\mathrm{a}}$ & 68.51 \\
\hline Genotypes & & & & $68.89^{\mathrm{ab}}$ \\
\hline Cahuil & $4.16^{\mathrm{a}}$ & $7.66^{\mathrm{a}}$ & $15.67^{\mathrm{b}}$ & $1.80^{\mathrm{a}}$ & $66.94^{\mathrm{b}}$ \\
Atlas & $3.59^{\mathrm{b}}$ & $7.71^{\mathrm{a}}$ & $18.49^{\mathrm{a}}$ & $1.65^{\mathrm{b}}$ & $69.37^{\mathrm{a}}$ \\
Moradas & $3.49^{\mathrm{b}}$ & $6.09^{\mathrm{b}}$ & $15.01^{\mathrm{c}}$ & $1.78^{\mathrm{a}}$ & $70.22^{\mathrm{a}}$ \\
2-want & $3.47^{\mathrm{b}}$ & $6.25^{\mathrm{b}}$ & $15.14^{\mathrm{c}}$ & $1.47^{\mathrm{c}}$ & \\
\hline
\end{tabular}

Different capital letters in the same column show significance between water conditions at $\mathrm{P}<0.05$ by Turkey.

\section{Materials and methods}

\section{Plant materials}

This study used four introduced quinoa genotypes including Cahuil, Moradas (from Chile), Atlas (from the Netherlands) and 2-want (from Argentina).

\section{Experimental conditions}

The experiments were conducted in the rainy season (June to September 2018) and dry season (November 2018 to January 2019) at the Faculty of Agriculture and Forestry, Tay Nguyen University $\left(12^{\circ} 39^{\prime}\right.$ North, $108^{\circ} 1^{\prime}$ East, elevation of
431 meters), Buon Me Thuot city, Dak Lak province, Vietnam - the representative area of the Central highland's cultivated conditions. Fig. 1 shows the meteorological conditions with air temperature in the rainy season ranged from 22.3 to $26.6^{\circ} \mathrm{C}$ with an average of $24.8^{\circ} \mathrm{C}$, where air humidity ranged from 76.0 to $96.0 \%$ with an average of $85 \%$. Total rainfall in this season was $865.8 \mathrm{~mm}$, which was uniformly divided into four months of the experimental period. There were no clear differences in air temperature and air humidity in the dry season compared to those in the rainy season, with an average of about $1.7^{\circ} \mathrm{C}$ and $3 \%$ lower, respectively. Difference in rainfall distribution was remarkable between two cropping seasons, where total rainfall was $109.1 \mathrm{~mm}$, which was just one-eighth of that in the rainy season, mostly 
in the first 20 days of the growing cycle, and a few days at blooming and seed formation stages. The experimental soil is red basalt type with a pH of 6.01 , as well as soil properties of $0.18 \% \mathrm{~N}, 10.8 \mathrm{mg} \mathrm{P}_{2} \mathrm{O}_{5} 100 \mathrm{~g}^{-1}$ and $11.0 \mathrm{mg} \mathrm{K}_{2} \mathrm{O} 100 \mathrm{~g}^{-1}$.

\section{Experimental design}

The current study applied a split-plot design with three replications for experiments in both seasons.

Four introduced quinoa genotypes were assigned in subplots. In the main-plot, four plant densities D1 (13.3 plants $\mathrm{m}^{-2}$ ), D2 (10.0 plants $\left.\mathrm{m}^{-2}\right), \mathrm{D} 3\left(8.0\right.$ plants $\left.\mathrm{m}^{-2}\right)$ and D4 (6.6 plants $\mathrm{m}^{-2}$ ) corresponded to a row distance of $50 \mathrm{~cm}$ and plant distances of $15,20,25$ and $30 \mathrm{~cm}$, respectively.

\section{Crop management}

Five seeds per hill were sowed at $2-3 \mathrm{~cm}$ of depths, then thinned to one plant per hill at 2-3 leaves stage. The experimental plot size was $14 \mathrm{~m}^{2}(5 \times 2.8 \mathrm{~m})$. Fertilizer was applied containing $1000 \mathrm{~kg}$ Huco microorganism, 500kg lime, $90 \mathrm{~kg} \mathrm{~N}, 60 \mathrm{~kg} \mathrm{P}_{2} \mathrm{O}_{5}$ and $60 \mathrm{~kg} \mathrm{~K}_{2} \mathrm{O}$ ha $^{-1}$ (Dinh et al., 2015). Quinoa plants grew under rain-fed conditions with water supplements at the sowing date to ensure seed germination. There were regular crop management practices to control pests, diseases, and weeds.

\section{Data collection}

At harvest, ten plants in each sub-plot were randomly taken from above ground to measure plant height, panicle length, panicle number per plant and number of seed per panicle. Then, panicles of sample plants were sun-dried for 3 days, threshed and winnowed by hand to determine the 1000seed weight and individual seed yield. The remaining plants in each plot were harvested to estimate actual or harvested yield. Following harvest, seed samples were oven-dried at $60^{\circ} \mathrm{C}$ until constant weight to determine the contents of fat, fiber, protein, ash, and starch according to Eisa et al.'s (2018) methods. All data were subjected to analysis of variance according to a split-plot designed using Statitix 8 package.

\section{Conclusions}

In conclusion, changes in plant density significantly affected panicle length, panicle number, seed number, 1000-seed weight, individual and actual yield, protein and ash contents, but plant density did not significantly affect plant height, fat, fiber, and starch contents. Eighty thousand plants ha ${ }^{-1}$ was the most suitable plant density for the highest seed yield and seed quality. Quinoa adapted well in the Central highland with better performance in the dry season. Among quinoa genotypes, Atlas and Cahuil performed best in the Central highland conditions.

\section{Acknowledgment}

The quinoa seeds were provided by Prof. Dr. Daniel Bertero, University of Buenos Aries, Argentina; Dr. Robert Van Loo, Wageningen Plant Research, Netherland; and Prof. Dr. Peter J. Maughan, Brigham Young University, United State of America. We are grateful for the financial support throughout the project "Quinoa varietal selection and product development for suitable ecological areas in
Vietnam", which was funded by the Ministry of Science and Technology, Vietnam from 2017-2020.

\section{References}

Bertero HD, Vega AJDL, Correa G, Jacobsen SE, Mujica A (2004) Genotype and genotype-by-environment interaction effects for grain yield and grain size of quinoa (Chenopodium quinoa Willd) as revealed by pattern analysis of international multi-environment trials. Field Crop Res. 89:299-318.

Delatorre J, Arenas J, Lanino M, Muňoz R, Tapita R (1995) Efecto de la densidad sobre el rendimiento en quinua (Chenopodium quinua) en la Pampa del Tamarugal. En Simiente. 65:1-3.

Delatorre J (2003) Current use of quinoa in Chile. Food Rev Int. 19(1\&2):155-165.

Dinh TH, Kawepradit, Jogloy S, Vorasoot N, Patanothai A (2013) Biological nitrogen fixation of peanut genotypes with different levels of drought tolerance under midseason drought. SABRAO J Breed Genet. 45(3):491-503.

Dinh TH, Kaewpradit W, Jogloy S, Vorasoot N, Patanothai A (2014) Nutrient uptake of peanut genotypes with different levels of drought tolerance under midseason drought. Turk J Agric For. 38:495-505.

Dinh TH, Nguyen TC, Nguyen VL (2015) Effect of nitrogen on growth and yield of quinoa accessions. J Sci Devel. 13(2): 173-182.

Dinh TH, Takaragawa H, Kawamitsu Y (2018) Nitrogen use efficiency and drought tolerant ability of various sugarcane varieties under drought stress at early growth stage. Plant Prod Sci. 22(2):250-261.

Eisa SS, Abd El-Samd EH, Hussin SA, Ali EA, Ebrahim M, González JA, Ordano M, Erazzú LE, El-Bordeny NE, AbdelAti AA (2018) Quinoa in Egypt - Plant density effects on seed yield and nutritional quality in Marginal regions. Middle East J Appl Sci. 8(2):515-522.

Erazzú LE, González JA, Buedo SE, Prado FE (2016) Effects of sowing density on Chenopodium quinoa (quinoa) Incidence on morphological aspects and grain yield in Var. CICA growing in Amaicha del Vall (Tucumán, Argentina). Lilloa. 53(1):12-22.

FAO- Food Agriculture Organization of the United Nations. (2011) Quinoa: An ancient crop to contribute to world food security. Regional Office for Latin America and the Caribbean, July 2011.

FAO- Food Agriculture Organization of the United Nations. (2013) International year of quinoa. http://www.fao.org/quinoa-2013/en.

Isobe $K$, Sato R, Sakamoto S, Arai T, Miyamoto M, Higo M, Torigoe $Y$ (2015) Studies on optimum planting density of quinoa (Chenopodium quinoa Willd.) variety NL-6 considering efficiency for light energy utilization, matter production yield. Jpn J Crop Sci. 84(4):369-377.

Maliro MFA, Njala AL (2019) Agronomic performance and strategies of promoting quinoa (Chenopodium quinoa Willd) in Malawi. Cien Inv Agr. 46(2):82-99.

Naneli I,Tanrikulu A, Dokuyucu T (2017) Response of the quinoa genotypes to different locations by grain yield and yield components. Int J Agri Innov Res. 6(3):447-451.

Nguyen VL (2016a) Effects of salinity stress on growth and yield of quinoa (Chenopodium quinoa Willd.) at flower initiations stages. Vietnam J Agri Sci. 14(3):321-327.

Nguyen VL (2016b) Genetic variation in response to salt stress of quinoa grown under controlled and field conditions. Int J Adv Sci Eng Inf Technol. 6(2):233-238. 
Nguyen IT, Tran TT, Nguyen TC, Ton TS (2018) Effect of nitrogen rate and plant density on yield of quinoa (Chenopodium quinoa Willd). Soil Sci. 49:32-37.

Nguyen TTH, Nguyen VL, Bie KCAJM, Ciampitti I, Nguyen AD, Nguyen VM, Nieto L, Schwabert R, Nguyen VL (2020) Mapping maize cropping patterns in Dak Lak, Vietnam through MODI EVI time series. Agronomy. 10:478.

Präger A, Munz S, Nkebiwe PM, Mast B, Graeff S (2018) Yield and quality characteristics of different quinoa (Chenopodium quinoa Willd.) cultivars grown under field conditions in Southwestern Germany. Agronomy. 8:197.

Spehar CR, Rocha JEDS (2009) Effect of sowing density on plant growth and development of quinoa, genotype 4.5, in the Brazilian savannah highlands. Biosci J. 25(4): 53-58.

Sief AS, El-Deepah HRA, Kamel ASM, Ibrahim JF (2015) Effect of various inter and intra spaces on the yield and quality of quinoa (Chenopodium quinoa Willd.). J Plant Product. 6(3):371-383.
Santis GD, Maddaluno C, D’Ambrosio T, Rascio A, Rinaldi M, Troisi J (2016) Characterisation of quinoa (Chenopodium quinoa Willd.) accessions for the saponin content in Mediterranean environment. Ital J Agron. 11:277-281.

Tan M, Temel S (2018) Performance of some quinoa (Chenopodium quinoa Willd.) genotypes grown in different climate conditions. Turk J Field Crops. 23(2):180-186.

Trinh CT, Ho CT, Luong DL (2019) Basal soil in Central highland. In: Nguyen XL et al. (ed) Results of scientific study and extension. Agricultural Publisher, Hanoi, Vietnam.

Trinh ND (2001) Study to develop quinoa (Chenopodium quinoa Willd) in North Vietnam (Doctoral thesis). Agricultural Academy publishing house, Hanoi, Vietnam.

World Bank- The Vietnam Development Report (2016) Transforming Vietnam agriculture: Gaining more from less. Hong Duc publishing house, Hanoi, April 2016. 